\title{
An analysis of factors affecting the adoption of economic and productive data recording methods of Chilean farmers
}

\author{
Alejandra Engler, ${ }^{1}$ and Roger Toledo ${ }^{2}$ \\ ${ }^{1}$ Departamento de Economía Agraria, Facultad de Ciencias Agrarias, Universidad de Talca, Casilla 747 \\ Talca, Chile. \\ ${ }^{2}$ Departamento de Economía Agraria, Instituto de Investigaciones Agropecuarias INIA Quilamapu, Casilla \\ 426 Chillán, Chile.
}

\begin{abstract}
A. Engler, and R. Toledo. 2010. An analysis of factors affecting the adoption of economic and productive data recording methods of Chilean farmers. Cien. Inv. Agr. 37(2): 101- 109. Integration of the Chilean domestic economy into international markets has created the need to incorporate more technology, information, and management tools and to generate better entrepreneurial skills at the farm level. These changes require the development of strategic capabilities and farmer changes in attitude. The goal for farmers is to be more prepared for the decision-making process and to have adequate evaluation and control systems to face the complexity of the farm business. The literature suggests that using management tools positively correlates with profits and concludes that management skills are positively related to farmers' well-being. Survey information on 211 farmers from central and southern Chile was used to estimate a probit model where the dependent variable was record-keeping by farmers. The results show that the farmers' educational level, age, membership a Technological Transfer Group, land leasing, and the farmers' own perception of their aversion to risk are statistically significant variables in the model. The model goodness of fit is 0.41 , and the model has good predictive power for groups of farmers.
\end{abstract}

Key words: Record-keeping, management skills, probability models.

\section{Introduction}

Past decades, the Chilean agricultural sector has evolved into a more specialized business by increasing product and export value. In the last decade alone, the agricultural PIB increased 1.3 times, while the export value grew 2.7 times (ODEPA, 2009). The development of the sector has allowed the country to set the short-run objective of becoming a member of the top ten

Received July 23, 2009. Accepted August 21, 2009. Corresponding author: mengler@utalca.cl agri-food exporters. However, this goal demands developing a more competitive and inclusive agriculture along with the agri-food supply (Barrera, 2005). To meet this challenge, large and small farmers will need to incorporate more technology, information, and management tools and to develop better entrepreneurial skills, all of which imply developing strategic capabilities and a change of attitude (McElwee et al., 2006).

Some of the required skills can be achieved by developing effective management strategies, making informed decisions, and having better evaluation and control systems for the farm 
business. Controlling economic and productive results of the agricultural activity leads to efficient business management. El-Osta et al. (2007) even conclude that management skills are positively related to the well-being of farmers. Moreover, there are studies that reveal that computer use on the farm is positively correlated to profitability, indicating that the use of information in decision making increases business performance (Gelb et al. 2001). Nuthall (2004) concludes that even though he could not find a relationship between computer use and profitability, computer use does allow farmers to methodologically collect, enter, and interpret data, all of which has a synergistic effect on mental decisions. The primary use of computers on the farm is record-keeping. According to Batte (2005), 89.1\% of a sample of farmers in Ohio, USA indicated that their primary use of computers was for keeping financial and economic records, and $76.7 \%$ think keeping records is one of the most important applications.

Governmental and private institutions in Chile have been generating mechanisms to help farmers keep and analyze economic and productive information. As a result of these initiatives, several Management Centers (MCs) have been created throughout the country since the late 1990 s to implement economic record-keeping to support the decision-making process of their associated farmers. Each MC was created to group farmers of the same geographic area, having the same or different agricultural activities. The farmer is visited by a professional of the MC staff once a month to collect economic information and to give him/her feedback on the monthly expense and income statements prepared by the MC. Each MC holds an annual workshop to analyze the final economic results of each crop. The dynamics of the MCs have allowed farmers to (i) know the results of each of their productive activities, (ii) improve efficiency in aspects where they had higher costs compared to the group, and (iii) increase profits on the whole. MC managers generally report that farmers have increased profits since they have been participating in the MC (Managers of Cer Los Lagos and CEAgroChile, personal communication).

After a decade, only a small portion of the potential farmer population is made up of MC clients or associates. The need today is to develop and increase farmers' management abilities, and a relevant concern is the capacity farmers have to process information for decision making. Keeping economic and financial records are the first steps in promoting modern management tools in the farming business. Record-keeping is essential in building up management skills and making informed decisions. The objective of this paper is twofold: first, to identify how popular the practice of keeping digital economic and/or productive records is in the Chilean agricultural sector, and second, to determine which factors favor a higher probability of keeping such records. Understanding of these factors will permit policy makers to create incentives to improve farmers' management abilities and will allow MCs to focus their marketing strategy on farmers who are more willing to adopt advanced management practices.

To address these objectives, we administered a comprehensive survey to a sample of farmers from central and southern Chile. The survey collected current management and recordkeeping practices utilized by farmers, as well as farm and farmer characteristics. A probit model was estimated to assess the probability of implementing a record-keeping system. Probability models have been extensively used in adoption literature (technology, quality measures, standards, and management tools) and are, therefore, a suitable model for our purposes (Ampansah, 1995; Hoag et al., 1999; Batte et al., 2005).

\section{Materials and methods}

\section{Description of sample and data collection}

Factors that influence the use of computers on the farm or the use of data in the decision- 
making process have been analyzed in previous literature (Nuthall, 2004; Batte, 2005; Just et al., 2003). The main conclusions have been the relevance of both demographic variables and agricultural system factors. Education, business size, off-farm income, investments, and regional location have been found to be particularly significant (Batte, 2005; Just et al., 2003). Byma and Tauer (2007) found that, along with higher operator education and larger farm size, other factors contributing to increased farm operation efficiency were extended participation in a farm management program and younger farmer age. Using these results, our study was based on statistical analyses of a survey of a random sample of 400 farmers from central and southern Chile, including the Bio-Bio, La Araucanía, Los Lagos, and Los Ríos Regions (In 2008, the Los Lagos and Los Rios Regions started operating as separate administrative areas. When the survey was conducted, both corresponded to the Los Lagos Region; therefore, the Los Lagos Region includes the two new regions in this article). In-person surveys were conducted between May and August 2006. From the original sample, only 358 were correctly completed and used in the study. The Bio-Bio, La Araucanía, and Los Lagos Regions turned out 136, 112, and 110 surveys, respectively. For the study at hand, only farmers who keep digital records and farmers who do not keep any records were considered. By using this selection criterion, the sample was reduced to 211 observations, in which 159 farmers declared keeping digital records, and 52 did not keep any records. The remaining 147 farmers who declared keeping records in notebooks were left out in order to generate a strong differentiation between farmers who use and do not use records in their management. The criterion was selected using the argument that the computer allows farmers to methodologically collect, enter, and interpret data (Nuthall, 2004). Furthermore, onfarm information will provide the farmer with a decision-making tool to evaluate and control his/her business (Amponsah, 1995).

Agriculture is considered a traditional occupation in the area studied, although farming systems vary throughout the zone. The most important activities are cereals, dairy, and cattle farming. The three regions accounted for approximately $33 \%$ of the national agricultural production in 2008 , including $92 \%$ of milk, $78 \%$ of wheat, and $57 \%$ of bovine meat in 2007 (ODEPA, 2009).

\section{Estimation procedure}

The dependent variable was constructed as a binary variable and assigned the value 1 for farmers who kept productive and/or economic records digital form and 0 for those farmers who did not have records of any kind. Based on the approach of rational choice theory (Chai, 2001) in which individuals are assumed to be purposive and intentional and in which decisions and actions are shaped by rational preferences and constraints, we argue that keeping records for decision-making is a choice related to farmer and farm system characteristics. Following this approach, a farmer $i$ is likely to adopt records if the utility of adopting, $U_{i 1}$, is greater than the utility of not adopting, $U_{i 0}$, as shown in equation 1 :

(1) $\left\{\begin{array}{l}U_{i 1}=\beta^{\prime} Z_{i 1}+\varepsilon_{i 1} \\ U_{i 0}=\beta^{\prime} Z_{i 0}+\varepsilon_{i 0}\end{array}\right.$

where $Z_{i 1}$ is a vector of farmer and farm system characteristics associated with choosing to keep records, $Z_{i 0}$ are characteristics associated with not keeping them, $\beta$ is a vector of parameters to be estimated, and $\varepsilon_{i 1}$ and $\varepsilon_{i 0}$ are random error terms assumed to follow a normal distribution. Therefore, the probability of adoption can be expressed as $P\left(U_{i 1}>U_{i 0}\right)=P\left(\beta^{\prime} Z_{i 1}-\beta^{\prime} Z_{i 0}>\varepsilon_{i 0}-\varepsilon_{i 1}\right) \quad$ o $\quad \mathrm{r}$ $P\left(y_{i}^{*}>0\right)=P\left(\varepsilon_{i}^{*}>-\alpha^{\prime} X_{i}\right)$, where $y_{i}^{*}$ states the differences in utility, $\varepsilon_{i}^{*}$ the difference in error terms, and $\alpha^{\prime} X_{i}$ is the systematic component of the equation that includes all farmerand farm-system characteristics referred to as the index function (Greene, 2003). The above-mentioned equation is known as the latent regression model where the variable $y_{i}^{*}$ is not observable and can be linked to $y_{i}=1$ when $y_{i}^{*}>0$. For $P\left(y_{i}=1\right)=F\left(\alpha^{\prime} X_{i}\right), \mathrm{F}$ is the 
normal cumulative distribution function that depends on $\alpha$ and $X_{i}$ parameters and variables. Parameters of the model were estimated by maximum likelihood estimators with NLogit 4.0.

\section{Results and discussion}

\section{Data description}

The dependent variable, digital record-keeping as explained in the methodology, was a binary variable whose value was 1 when the surveyed farmer kept productive and/or economic digital records and 0 when he/she did not. Table 1 provides a detailed explanation of the independent variables used in the model. They were divided into the following two groups: (i) farmer characteristics that included age (age), educational level $(e d u)$, own perception of risk-aversion (relav), membership in a Management Center $(M C)$ and Technological Transfer Group (TTG); and (ii) farm system characteristics including size (size), income sources (inc), and leased land (lease). A summary of the variable statistics is presented in Table 2.

It can be observed from the descriptive statistics that $25 \%$ of the sample did not keep records of any kind, meaning that $75 \%$ kept digital records of his/ her activities. Was a difference between the two groups regarding their participation in MCs and TTGs. In both cases, the proportion of farmers who participated in these initiatives was higher in the digital record-keepers. This was expected because farmers associated with an $\mathrm{MC}$ are more interested in using information and improving management skills, or they at least consider management as a relevant business factor. Technological Transfer Groups, which were created to increase opportunities for sharing knowledge and technology between farmers, were also expected to influence recordkeeping since management tools are one of the topics discussed and analyzed in the group meetings along with technological topics. The age and education level variables also exhibited differences between groups. The group

Table 1. Description of independent variables.

\begin{tabular}{|c|c|c|}
\hline Code & Description & Type of variable \\
\hline lease & $\begin{array}{l}1=\text { Farm uses leased land } \\
0=\text { otherwise }\end{array}$ & Binary variable \\
\hline TTG & $\begin{array}{l}1=\text { Belongs to a Technological Transfer Group. } \\
0=\text { otherwise }\end{array}$ & Binary variable \\
\hline $\mathrm{MC}$ & $\begin{array}{l}1=\text { Belongs to a Management Center } \\
0=\text { otherwise }\end{array}$ & Binary variable \\
\hline Age & Age of the producer & $\begin{array}{l}\text { Continuous, measured in } \\
\text { years }\end{array}$ \\
\hline Edu & $\begin{array}{l}\text { Categorical variable that indicates the level of education from } 1 \text { to } 11 \text {, where } \\
1 \text { means no education and } 11 \text { means a graduate degree. }\end{array}$ & Discrete \\
\hline Relav & $\begin{array}{l}\text { Categorical variable that measures the farmers' perception of his/her risk- } \\
\text { aversion. The categories are: } 1=\text { the farmer is willing to take more risks than the } \\
\text { mean only on a few occasions, } 2=\text { the farmer is willing to take more risks than } \\
\text { the mean on some occasions, and } 3=\text { is generally willing to take more risks. }\end{array}$ & Discrete \\
\hline Inc & $\begin{array}{l}\text { Categorical variable that indicates the proportion of the total income that is } \\
\text { derived from agricultural activities: } 1=\text { low proportion, } 2=\text { close to } 50 \% \text {, } \\
3=\text { high proportion, } 4=100 \% \text {. }\end{array}$ & Discrete \\
\hline Size & Total hectares dedicated to the business. & $\begin{array}{l}\text { Continuous, measured in } \\
\text { hectares }\end{array}$ \\
\hline
\end{tabular}


Table 2. Characteristics of farmers, farm systems, and groups with and without digital record-keeping.

\begin{tabular}{|c|c|c|c|}
\hline Variable & Description & No record-keeping & Digital record-keeping \\
\hline & Number of farmers & $\begin{array}{c}52 \\
25 \%\end{array}$ & $\begin{array}{l}159 \\
75 \%\end{array}$ \\
\hline \multicolumn{4}{|c|}{ Farmer characteristics } \\
\hline Age & Mean age & 56 years & 47 years \\
\hline Edu & $\begin{array}{l}\text { Category mean of } \\
\text { educational level from } 1 \text { to } \\
11 \text { (higher category implies } \\
\text { higher educational level). }\end{array}$ & 5 & 8 \\
\hline Relav & $\begin{array}{l}\text { Percentage of farmers in a } \\
\text { risk-aversion category. }\end{array}$ & $\begin{array}{l}\text { 1.: Will rarely take more risk than the } \\
\text { mean: } 54 \% \\
\text { 2. Will take more risk than the mean on } \\
\text { some occasions: } 31 \% \\
\text { 3. Will generally take more risk than the } \\
\text { mean : } 15 \%\end{array}$ & $\begin{array}{l}\text { 1. Will take more risk than the } \\
\text { mean: } 35 \% \\
2 \text {. Will take more risk than the } \\
\text { mean on some occasions: } 41 \% \\
\text { 3. Will generally take more } \\
\text { risk than the mean: } 24 \%\end{array}$ \\
\hline TTG & $\begin{array}{l}\text { Percentage of farmers } \\
\text { participating in a } \\
\text { Technological Transfer } \\
\text { Group. }\end{array}$ & $12 \%$ & $40 \%$ \\
\hline $\mathrm{MC}$ & $\begin{array}{l}\text { Percentage of farmers } \\
\text { participating in a } \\
\text { Management Center. }\end{array}$ & $8 \%$ & $45 \%$ \\
\hline \multicolumn{4}{|c|}{ Farm system characteristics } \\
\hline Size & $\begin{array}{l}\text { Mean size of the } \\
\text { productive system }\end{array}$ & 281.9 ha & 533 ha \\
\hline Inc & $\begin{array}{l}\text { Percentage of farmers } \\
\text { in each income source } \\
\text { category. }\end{array}$ & $\begin{array}{l}\text { 1. Low proportion derived from } \\
\text { agriculture: } 13 \% \\
\text { 2. Close to } 50 \% \text { derived from } \\
\text { agriculture: } 13 \% \\
\text { 3. High proportion derived from } \\
\text { agriculture: } 23 \% \\
\text { 4. All income derived from agriculture: } \\
50 \%\end{array}$ & $\begin{array}{l}\text { 1. Low proportion derived } \\
\text { from agriculture: } 14 \% \\
\text { 2. Close to } 50 \% \text { derived from } \\
\text { agriculture: } 9 \% \\
\text { 3. High proportion derived } \\
\text { from agriculture: } 36 \% \\
\text { 4. All income derived from } \\
\text { agriculture: } 41 \%\end{array}$ \\
\hline Lease & $\begin{array}{l}\text { Percentage of farmers who } \\
\text { lease land. }\end{array}$ & $29 \%$ & $50 \%$ \\
\hline
\end{tabular}

of record-keepers tended to be younger and to have achieved a higher educational level. In this group, the mean educational category was 8 (technical certification from a professional institute), while in the non-record-keeper group, the mean category was 5 (high school completion). These results were consistent with Batte's (2005) findings analyzing computer use by farmers in Ohio, USA.

When analyzing differences in the production between groups, there was an evident differ- ence in size. Record-keepers tended to have larger farms with a mean of 533 hectares, and non-record-keepers 281.9 hectares. The income source distribution was similar in both groups, with approximately $75 \%$ of farmers reporting that either most or all of their income comes from agricultural activities. However, in the non-record-keeper group, the percentage of farmers whose income was exclusively derived from agriculture was higher. On the other hand, the percentage of farmers who leased land was higher in the record-keeper 
group. We argue that producers who lease land need to control better the results of each activity in order to evaluate the convenience of future leasing.

Finally, another variable considered in the study was the farmers' own perception of their aversion to risk. The question asked how often they were willing to take more risk compared to other farmers. Twenty-four percent of the record-keepers reported generally taking more risks than other farmers, whereas only $15 \%$ of the non-record-keeper group made this statement. Thus, on average, digital record-keepers declared themselves less risk-averse.

The descriptive statistics reveal that there were significant differences between the two groups of farmers. The tendency showed record-keepers as younger, more educated, less risk-averse, and more likely to be leasing land. The probability model in the next section answers the question of how relevant each of these factors was in determining the use of records.

\section{Estimation results}

Estimation results are shown in Table 3. The coefficients reported correspond to maximum likelihood estimators which indicate the greatest probability of obtaining the observed value. The coefficient signs determine the direction of the effect of the variables on the probability that the farmer will keep records. The model was estimated correcting for heteroscedasticity using a variance function for $M C$ and inc. The distribution of the variance function was not significant for the other variables included in the model. The model performance can be rated as slightly strong because it presents an Estrella criterion value of goodness of fit of 0.41. Estrella measures goodness of fit of binary dependent variable regressions by using a transformation of the log-likelihood function. The measure is comparable to $\mathrm{R}^{2}$ in terms of its range and the underlying relationship with the test statistics, and it is therefore a suitable measure for the estimated model. The interpretation of the interior point can be assimilated to the same range used for $\mathrm{R}^{2}$, where a 0.25 value or lower is considered weak, 0.5 to 0.74 strong, and 0.75 or higher as very strong (Estrella, 1998). Moreover, by analyzing the predictive success of the model, it can be observed that it correctly predicted a digital record-keeper $92 \%$ of the time, and a non-record-keeper $50 \%$ of the time, meaning the model had a high predictive power. The variables in the model that were significant included educational level, age, membership in a TTG, the producer's relative aversion to risk, and if the farm system had any leased land.

Previous studies identified age and educational level as relevant factors when predicting the use of information in decision making and computer use (Batte, 2005: Amponsah, 1995). According to our results, both variables were highly significant with less than $1 \%$ probability of rejection. As expected, when educational level increased, the probability of keeping records was higher. For the age variable, the coefficient indicates that older farmers were less likely to adopt digital records, a fact consistent with the field observations. In general, new generations of farmers are more conscious of running the farm as a business and of incorporating management tools in their decisions.

An interesting feature of the model was that belonging to a TTG also influenced the significance factor, and these farmers were more likely to keep digital records. In this case, TTG usually deal with technological issues because this is their primary objective, but many of them have been incorporating the use of management tools as a technological topic in their regular meetings, a fact which explains our results. On the contrary, belonging to an MC is not a significant variable. We expected that MCs would have motivated farmers to improve management abilities and make them more willing to adopt management tools. However, MCs keep records for their members and so it may be that these farmers do not feel the need to adopt a record-keeping system. The estimation result showed that are neutral in the probability of keeping digital records, which could be explained by the two hypotheses offsetting each other. As seen in the descriptive statistics, there 
Table 3. Estimation results of the probit model and goodness of fit measurements.

\begin{tabular}{|c|c|c|c|}
\hline Variable & Coefficient & Standard error & P-value \\
\hline \multicolumn{4}{|l|}{ Probability Index function } \\
\hline Constant & $2.88 * *$ & 1.23 & 0.02 \\
\hline Lease & $0.42 *$ & 0.25 & 0.09 \\
\hline TTG & $1.92 * * *$ & 0.74 & 0.009 \\
\hline $\mathrm{MC}$ & 0.49 & 0.62 & 0.42 \\
\hline Age & $-0.07 * * *$ & 0.02 & 0.001 \\
\hline Edu & $0.20 * *$ & 0.08 & 0.01 \\
\hline Relav & $-0.34 * * *$ & 0.13 & 0.009 \\
\hline Inc & 0.08 & 0.25 & 0.74 \\
\hline Size & -0.0001 & 0.00008 & 0.14 \\
\hline \multicolumn{4}{|l|}{ Variance function } \\
\hline $\mathrm{MC}$ & $-11.63 * * *$ & 0.28 & $<0.001$ \\
\hline Inc & $0.39 * * *$ & 0.11 & $<0.001$ \\
\hline Log-likelihood & -73.749 & & \\
\hline Restricted log-likelihood & -117.822 & & \\
\hline Estrella $=1-(\mathrm{L} / \mathrm{L} 0)^{-2 \mathrm{~L} 0 / \mathrm{n}}$ & 0.41 & & \\
\hline McFadden $\mathrm{R}^{2}$ & 0.37 & & \\
\hline Number of observations ${ }^{\text {a }}$ & 211 & & \\
\hline
\end{tabular}

Legend: ${ }^{*} \mathrm{p}<0.1 ; * \mathrm{p}<0.05 ; * * * \mathrm{p}<0.01$. McFadden R2 is calculated $R^{2}{ }_{M c F}=1-\left(\ln \hat{L}_{u} / \ln \hat{L}_{r}\right)$ as, where $\hat{L}_{u}$ is the unrestricted $\log$-likelihood function and $L_{r}$ is the restricted log-likelihood function. Count R2 is based on the table of observed and predicted outcomes and is calculated as $R_{\text {Count }}^{2}=1 / N-\sum_{j} n_{j j}$ where $n_{j j}$ represents the correct predictions for outcome $\mathrm{j}$.

was a higher participation in MCs among the digital record-keeper group. Nevertheless, from the aforementioned results, it can be inferred that the possibility of sharing the experience of using management tools, such as in the TTG, was an effective way to increase management ability among producers.

The lease variable, which indicated whether the farmer had leased land and had to pay annual rent, was also significant and positive, meaning that producers who needed to pay rent were more likely to adopt digital records of their business performance. This result is understandable in that farmers who lease land to increase their business were constantly evaluating the convenience of renting or not. Size of the farm was expected to be relevant in record-keeping. Larger farms manage more resources and for this reason it was expected that they would need more management tools to support decisions. Batte (2005) found that farm size measured in terms of total sales was significant for computer use as a management tool. Contrary to our hypothesis, size was not significant. This result revealed that small and large farmers have the same potential to increase their management ability, and the relevant variable in this case would be educational level and age, as already shown. Using the same arguments, we would have expected that as long as the agricultural activities represented a higher portion of the total income of the farmer, the probability of keeping records would increase, but the inc variable was not significant.

Finally, a variable was included in the model to capture the impact of the farmers' perception of their own aversion to risk. The hypothesis was that as farmers declared themselves more risk-averse, they would be more likely to adopt records. The variable was scaled in three levels where 1 represented more aversion and 3 less aversion. The results show that the variable was negatively significant, thus our hypothesis. 


\section{Conclusion}

The present study has provided strong evidence that the adoption of management tools, represented in this case by digital economic and productive information records, was affected by farmer and production system characteristics. Results were consistent with the theory of farmers as rational because producers who lease land and believe they are more riskaverse show a higher probability of keeping information to make decisions. On the other hand, size was not significant in the model and was not a relevant variable in the decision to keep information. The possibility of sharing experience through TTGs increased the probability of keeping digital records. Finally, younger farmers with higher levels of education were more willing to adopt digital records. Given these results, it can be concluded that an effective way to incorporate management tools throughout Chilean agriculture is by directing established groups of farmers to into the use of record keeping tool. What is more, younger farmers should be targeted, since they present a higher rate of adoption of computer tools.

\title{
Resumen
}

\begin{abstract}
A. Engler y R. Toledo. 2010. Análisis de los factores que afectan la adopción de métodos registros productivos y económicos entre productores chilenos. Cien. Inv. Agr. 37(2): 101-109. La integración de la economía chilena a los mercados internacionales ha creado la necesidad de incorporar más tecnología, información, nuevas herramientas de gestión y generar nuevas habilidades empresariales a nivel de predio, lo cual implica el desarrollo de capacidades estratégicas y un cambio en la actitud por parte de los agricultores. El objetivo para el agricultor es estar mejor preparados para la toma de decisiones y contar con sistemas de evaluación y control adecuados a la complejidad del negocio agrícola. La literatura sugiere que el uso de herramientas de gestión tiene una correlación positiva con los beneficios, lo que permite concluir que la capacidad de gestión incrementa las posibilidades de buenos resultados. A partir de una encuesta a 211 agricultores de la zona centro y centro sur de Chile se estimó un modelo probit, donde la variable dependiente corresponde a productores que mantienen registros digitales. Los resultados muestran que el nivel educacional del productor, edad, pertenencia a un Grupo de Transferencia Tecnológica, arriendo de tierra y la percepción personal respecto a aversión al riesgo son variables estadísticamente significativas. La bondad de ajuste del modelo es de 0,41, y presenta un buen nivel de predicción, para agricultores con diferente método de registro.
\end{abstract}

Palabras clave: Registro de datos, capacidad de gestión, modelos probabilístico.

\section{References}

Amponsah, W. 1995. Computer adoption and use of information services by North Carolina commercial farmers. Journal of Agricultural and Applied Economics 27: 565 - 576.

Barrera, A. 2005. La nueva institucionalidad pública alimentaria. In: Barrera, A., V. Venegas, T. Tom- ic, and H. Rojas (eds). Economía del crecimiento y Nueva Agricultura. LOM Ediciones Ltda. Santiago, Chile. 325 pp.

Batte, M. 2005. Changing computer use in agriculture: evidence of Ohio. Computers and Electronics in Agriculture 47: 1 - 13.

Byma, J., and L. Tauer. 2007. Exploring the role of managerial ability in determining firm efficiency. Paper presented at the Annual Meeting of the 
American Agricultural Economic Association. July 30,31 . Portland, Oregon, USA.

Chai, S.K. 2001. Choosing an Identity: A general model of preferences and belief formation. The University of Michigan Press. Ann Arber. 336 pp.

El-Osta, H., A. Mishra and M. Morehart. 2007. Determinants of economic well-being among U.S. farmers operators households. Agricultural Economics 36: 291-304.

Estrella, A. 1998. A new measure of fit for equations with dichotomous dependent variable. Journal of Business and Economic Statistics 16: $198-205$.

Gelb, E.M., C. Parker, P. Wagner, and K. Rooskoph. 2001. Why is the ICT adoption rate by farmers still so low? In: Summary of EFITA 2001 Conference Questionnaires and Symposium. Proceedings of the European Conference of Information Technology in Agriculture.
Greene, W.H. 2003. Econometric Analysis. 5th ed. Prentice Hall. Upper Saddle River, New Jersey, USA. 1026 pp.

Hoag, D., J. Ascough, and M. Frasier. 1999. Farm computer adoption in the Great Plains. Journal of Agriculture and Applied Economics 31: 57 - 67.

Just, R., S. Wolf, and D. Zilberman. 2003. Principles of risk management services relations in agriculture. Agricultural Systems 75: 199- 213.

McElwee, G., A. Anderson and K. Vesala. 2006. The strategic famer: a cheese producer with cold feet? Journal of Business Strategy 27: 65 -72 .

Nuthall, P. 2004. Case studies of the interactions of farm profitability and the use of a farm computer. Computers and Electronics in Agriculture 42: 19 -30 .

ODEPA. 2009. Statistical Databases. Available online at: www.odepa.cl Website accessed March, 2009. 
